\title{
The installation campaign of 9 seismic stations around the KTB site to test anisotropy detection by the Receiver Function Technique
}

\author{
I. Bianchi ${ }^{1}$, M. Anselmi ${ }^{2}$, M. T. Apoloner ${ }^{1}$, E. Qorbani ${ }^{1}$, K. Gribovski ${ }^{1,3}$, and G. Bokelmann ${ }^{1}$ \\ ${ }^{1}$ Institut für Meteorologie und Geophysik, Universität Wien, 1090 Wien, Austria \\ ${ }^{2}$ Sezione Sismologia e Tettonofisica, Istituto Nazionale di Geofisica e Vulcanologia, 00143 Roma, Italy \\ ${ }^{3}$ MTA CSFK Geodéziai és Geofizikai Intézet, 9400, Sopron, Csatkai E. u. 6-8, Hungary
}

Correspondence to: I. Bianchi (irene.bianchi@univie.ac.at)

Received: 11 May 2015 - Revised: 28 July 2015 - Accepted: 31 July 2015 - Published: 8 September 2015

\begin{abstract}
The project at hand is a field test around the KTB (Kontinentale Tiefbohrung) site in the Oberpfalz, Southeastern Germany, at the northwestern edge of the Bohemian Massif. The region has been extensively studied through the analysis of several seismic reflection lines deployed around the drilling site. The deep borehole had been placed into gneiss rocks of the Zone Erbendorf-Vohenstrauss. Drilling activity lasted from 1987 to 1994, and it descended down to a depth of $9101 \mathrm{~m}$.

In our experiment, we aim to recover structural information as well as anisotropy of the upper crust using the receiver function technique. This retrieved information is the basis for comparing the out-coming anisotropy amount and orientation with information of rock samples from up to $9 \mathrm{~km}$ depth, and with high-frequency seismic experiments around the drill site.

For that purpose, we installed 9 seismic stations, and recorded seismicity continuously for two years from June 2012 to July 2014.
\end{abstract}

\section{Tectonic setting of the study area}

The region hosting the deployed seismic stations has been focus of several geophysical investigations during the nineties (DEKORP Research Group, 1987, 1988; Eisbacher et al., 1989; Lüschen et al., 1996; Harjes et al., 1997; DEKORP and Orogenic processes Working Groups, 1999; Muller et al., 1999). Figure 1a shows surface geological units as well as seismic reflection lines around the drilling site. The deep borehole was placed into the gneiss rocks of the Zone Erbendorf-Vohenstrauss. An alternating sequence of parag- neisses and amphibolites was found, with metamorphism of upper amphibolite facies conditions. Ductile deformation produced a strong foliation of the rocks. Unexpected though was the steep inclination of that pervasive foliation, which did not correspond to previous interpretations of flat seismic reflections and mapped surface geology (Harjes et al., 1997). Previous tectonic interpretations had to be strongly modified, to explain the in-situ information from the borehole (Emmernann and Lauterjung, 1997; O'Brien et al., 1997). Principal results from the drilling and accompanying geophysical experiments are described in a special JGR volume (Haak and Jones, 1997; Emmermann and Wohlenberg, 1989).

Further geophysical experiments have been performed, especially a 3D seismic experiment around KTB, the ISO89 experiment (Fig. 1) (DEKORP Research Group, 1988; DEKORP and Orogenic processes Working Groups, 1999), as well as a Moving-Source Profiling (MSP) experiment that constrained the effective anisotropy of the upper eight kilometers (Okaya et al., 2004). This anisotropy is apparently not controlled by the faults, but instead by foliation and/or the stress-induced cracks. At mid-crustal depth, a high-conductivity zone had been suggested with maximum conductivity in North-South direction, which is perhaps consistent with the presence of a basal detachment horizon.

This metamorphic (anisotropy bearing) body was drilled till the whole length of the KTB drill. The expectations to reach the Saxothurignan-Moldanubian boundary below few kilometers of metamorphic rocks were betrayed at that time. The Saxothurignan (in the NW of the area) and Moldanubian (in the SE of the area) crustal terrains came in contact during the Variscan orogenesis. Their suture line should lie in the study area. 
a)

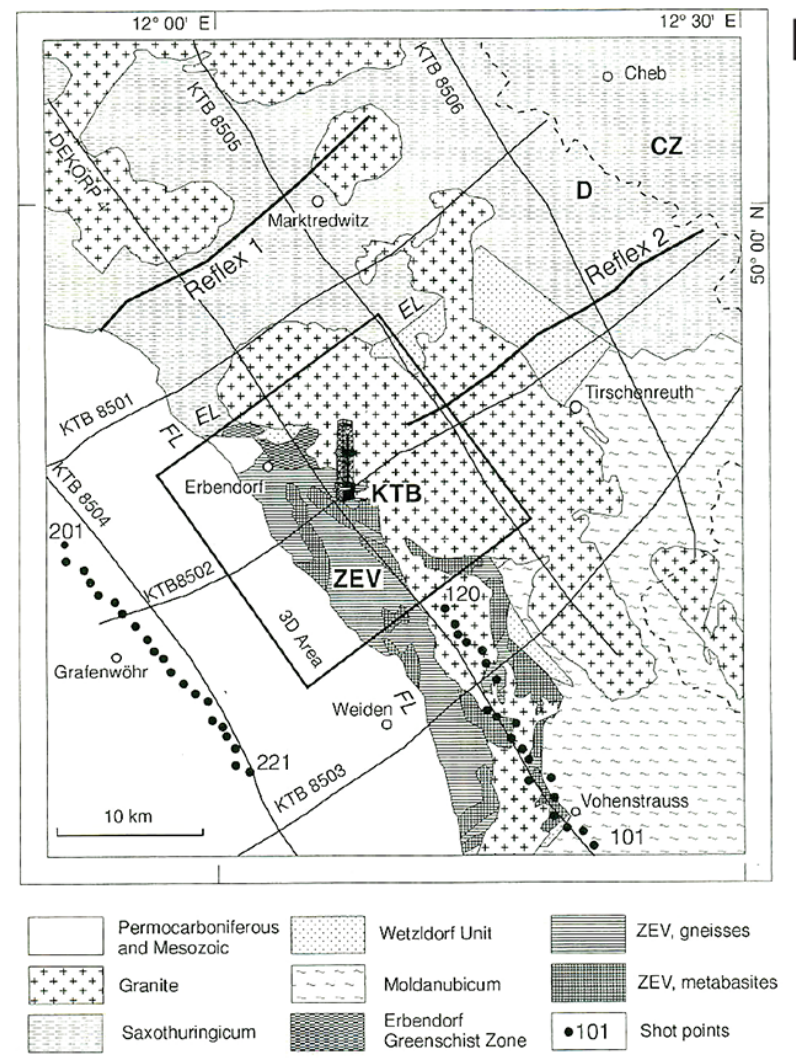

b

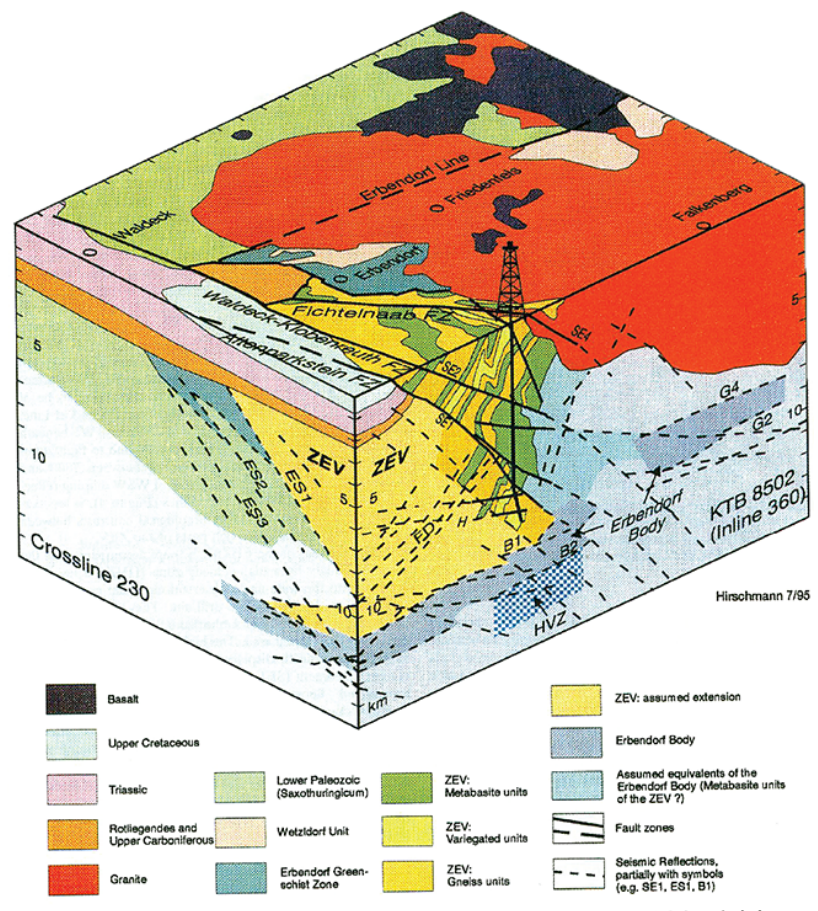

Figure 1. (a) Geology in the Oberpfalz region as well as seismic reflection lines (DEKORP Research Group, 1988; DEKORP and Orogenic processes Working Groups, 1999), and (b) a block diagram of the KTB area (Harjes et al., 1997).

Table 1. Station location.

\begin{tabular}{lllll}
\hline STAT & Locality & LON & LAT & ALT \\
\hline KW01 & Nottersdorf & 12.1192 & 49.8059 & 484 \\
KW02 & Arnoldsreuth & 12.0077 & 49.9239 & 616 \\
KW03 & Kölerhof & 12.2913 & 49.8195 & 558 \\
KW04 & Parkstein & 12.0846 & 49.7246 & 458 \\
KW05 & Altendorf & 11.9834 & 49.752 & 502 \\
KW06 & Lenkermühle & 12.1184 & 49.7762 & 499 \\
KW07 & Moosbach & 12.4533 & 49.5859 & 588 \\
KW08 & Öberholl & 12.225 & 49.668 & 545 \\
KW09 & Siegritz & 12.0682 & 49.8595 & 561 \\
\hline
\end{tabular}

\section{Scientific goal of the project}

The project performs a field test around the KTB (Kontinental Tiefbohrung) site in the Oberpfalz in Southeastern Germany. The primary purpose of this experiment is to test the receiver function technique, using both the radial and transverse components, and to compare it with previous results from deep drilling, and high-frequency seismic experiments around the drill site. Beside that primary goal, we also hope to shed light on the transition between the different crustal terrains in that area, i.e. the transition be- tween Saxothuringian and Moldanubian crustal terrains, and to study the deeper parts of that transition zone. If we can observe this transition especially detecting anisotropy by receiver functions, then there are many very promising applications of this technique.

The selected area is a perfect test laboratory due to the presence of the KTB drilling site. Crustal rocks were extracted till $9 \mathrm{~km}$ of depth, kept and classified few meters from the drill site; they are accessible to the public. Moreover the area was investigated by active seismic profiles, rendering accessible the knowledge of the shallow crustal structures. The final aim is to compare the anisotropy retrieved by receiver functions with anisotropy detected by previous studies; in this comparison the different frequency content of the measurements and the type of anisotropy must be considered. The wide-angle shots recorded by 3-component geophones in the KTB pilot hole provided convincing evidence for S-wave splitting in the upper crust SE of the KTB location. This anisotropy effect seemed to be related to the overall strike and dip of rock foliation (Gebrande et al., 1991). 


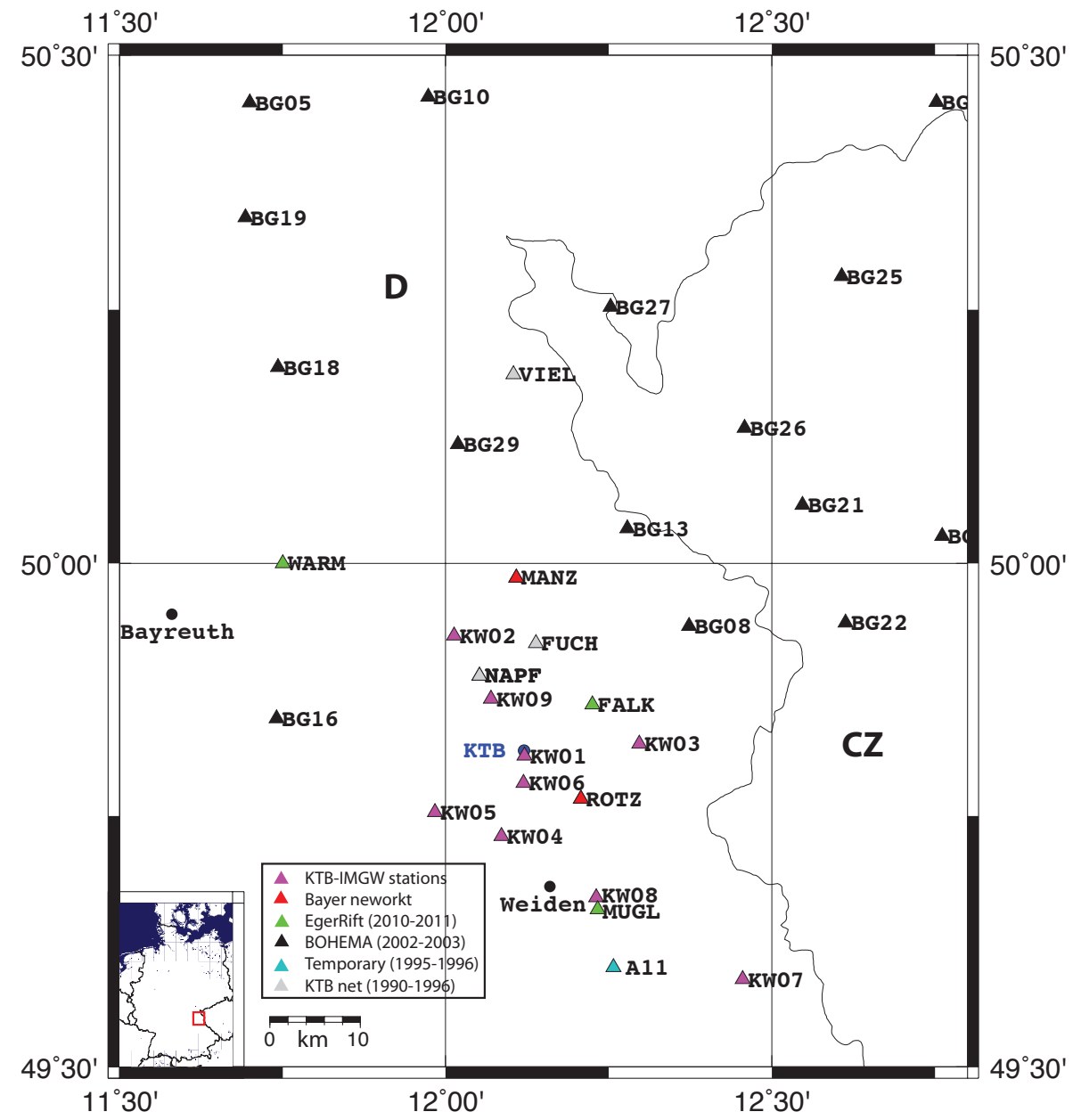

Figure 2. Map of the study are with seismic networks deployed in the study area since 1990. The blue circle represents the location of the KTB drilling site. In the inset a map of Germany with a red box displaying the location of the study area.

\section{Permanent and temporary networks in the area}

Before selecting the locations for the seismic station installations, we explored the literature to unravel the presence of seismic networks that ran or are still running in the area.

The permanent seismic Network in Bavaria, installed and maintained by the Geophysikalisches Observatorium der Ludwig-Maximilians Universität Ludwigshöhe in Fürstenfeldbruck is running in the study area. Stations of particular interest for this experiment are ROTZ and MANZ (Fig. 2). Recently (2010 to 2011) a broadband seismic network was installed in the area during the EgerRift experiment (e.g., Babuska and Plomerova, 2013) (Fig. 2). Records of the original KTB broadband network are available from 1990 to 1996 (Dahlheim et al., 1997). As part of a seismic broadband line the station A11 (Fig. 2) was deployed during 1995 to 1996 (Plenefisch et al., 2001). Between 2002 and 2003 broadband stations (Fig. 2) were installed over a broader area during the BOHEMA (BOhemian Massif Anisotropy and HEterogeneity) experiment (Plomerová et al., 2007). According to the recordings available of those previously installed stations, we installed 9 more stations (Table 1, Fig. 2) in order to re-trace the geometry of the DEKORP (Deutsches Kontinentales Reflexionsseismisches Programm) and KTB8502 (Fig. 1).

\section{The seismic deployment}

Network geometry has to consider the shape of the metamorphic Erbendorf-Vohenstrauss body, the location of the main active seismic profiles, and the location of previously installed seismic stations. Nine stations have been deployed to sample the metamorphic body and to highlight the structural differences in the shallow crust.

Each recording site is equipped with a Reftek 130-01 digitizer, and a sensor Reftek 151B-60 (Fig. 3). Before the installation of the temporary network a site search campaign was performed. The ideal site for the location of a seismic station is characterized by a low background seismic noise. This happens far away from cities, infrastructures, quarries, indus- 


\begin{tabular}{|c|c|c|c|c|}
\hline Instrument & Type & Picture & \multicolumn{2}{|c|}{ Technical characteristics } \\
\hline REFTEK & Digitizer & & Dynamics & $>135 \mathrm{db}$ \\
\hline $\begin{array}{l}\text { 130-1 } \\
{[\text { REF TEK] }}\end{array}$ & & & Resolution & $\begin{array}{l}24 \text { bit }- \\
20 \mathrm{VPP}\end{array}$ \\
\hline $\begin{array}{l}\text { REFTEK } \\
\text { 151B-60 }\end{array}$ & Sensor & & $\begin{array}{l}\text { Frequency } \\
\text { response }\end{array}$ & $\begin{array}{l}0.0166 \\
\mathrm{~Hz} \\
\mathrm{sec})\end{array}$ \\
\hline GARMIN & GPS antenna & & & \\
\hline & $\begin{array}{c}\text { GSM } \\
\text { antenna }\end{array}$ & & & \\
\hline DIGI & Modem & & & \\
\hline
\end{tabular}

Figure 3. From top to bottom: Reftek digitizer 130-01; seismic sensor Reftek 151-60; GPS Garmin antenna; GSM antenna; modem. All of them were used during the acquisition campaign.

trial areas, woods, rivers, lakes, and the sea. These conditions cannot always be met; moreover the final choice of the location was done on the basis of considerations that brought a compromise between these ideals locations, and the possibility of installing the stations inside buildings, in order to preserve their safety.

The stations where installed since July 2012 to October 2012 as standalone, station KW08 only was used as a test for the telemetric system. Since October 2012 all stations transmitted data through the telemetric system. The station configuration was set to a gain of 32 and sampling rates of 1 and $100 \mathrm{~Hz}$.

\section{Site characterization}

The estimate of the background noise of a determined site and its frequency content analysis is one of the most important criteria for establishing a good performance of a seismic station.

An estimate of the noise level of the sites was performed using $1 \mathrm{~h}$ of recorded noise (during daytime) for each installed station. The registered noise was analyzed by its spectral characteristics (Fig. 4).

The power-spectral-density (PSD) gives the power of the recording as a function of frequency, expressed in decibel (dB) (e.g. Marzorati and Bindi, 2006) and is used to verify the amount of noise for the selected sites. Beside this we 

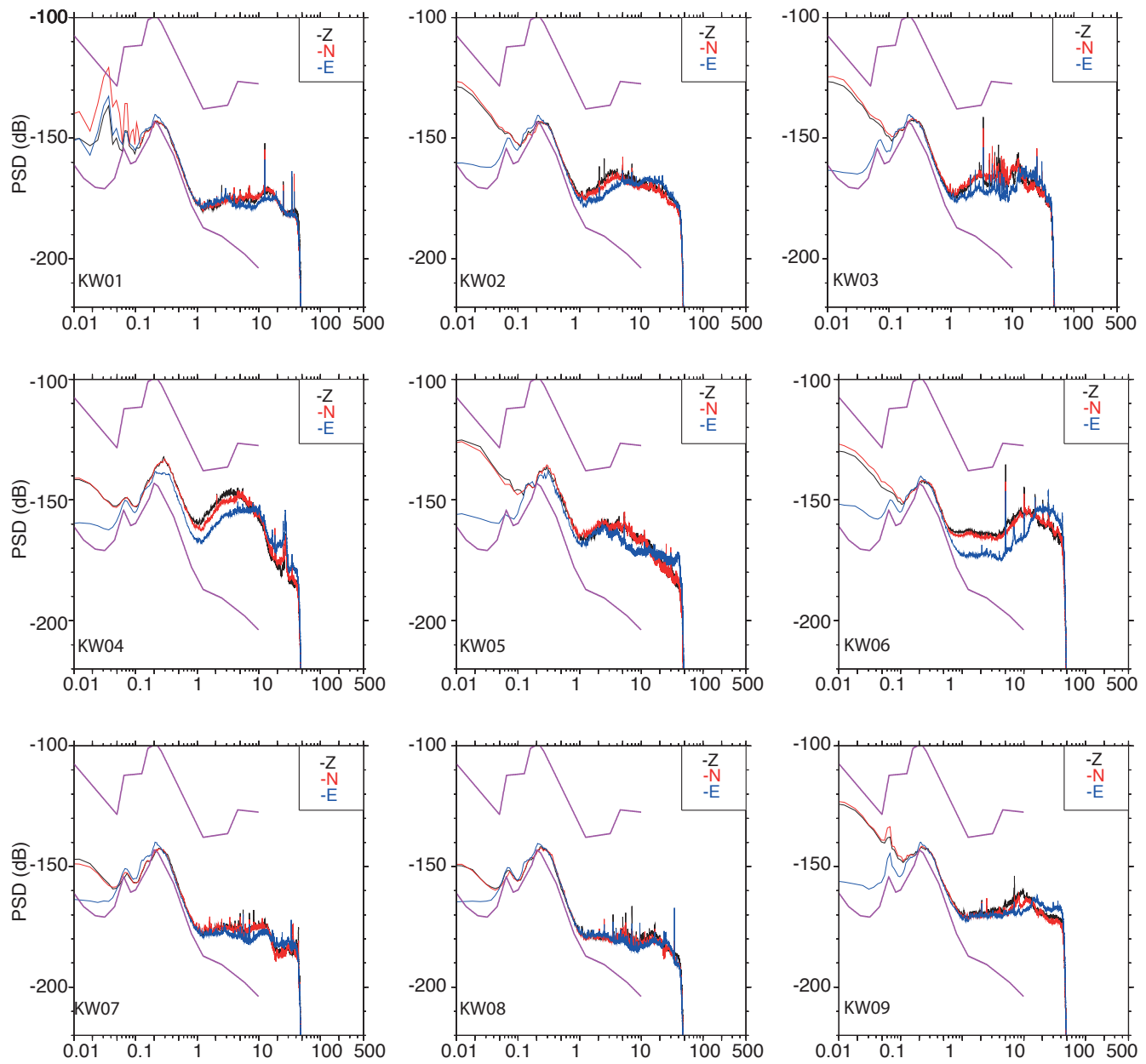

Figure 4. Power-spectral-density (PSD) in $\mathrm{dB}$ of the noise recorded at the stations. All sensors are $60 \mathrm{~s}$, sampling $100 \mathrm{~Hz}$. The top and bottom magenta lines represent the Peterson high- and low-noise curves (Peterson, 1993). Real spectra are located between these two curves. The $x$ axis shows frequency in $\mathrm{Hz}$.

analyzed the spectral ratio between the two horizontal components $(\boldsymbol{N}$ and $\boldsymbol{E})$ with respect to the vertical one (Z), in order to estimate the soil amplification characteristics as a frequency function for each horizontal component $(N$ and $\boldsymbol{E}$ ) separately (Fig. 5). This analysis is slightly modified after Nakamura (1989) that analyzes the $H / V$ ratio, where $H$ is the vector sum of the horizontal vectors $\boldsymbol{N}$ and $\boldsymbol{E}$.

To evaluate these results, we take into account the geological characteristics of the sites. The sites have been selected considering the geometrical needs of the network itself, and according to past seismic experiments data accessibility, in order to get the maximum rays coverage in the area. Most of the stations are located on the bedrock either of metamorphic or magmatic origin. The possibility to build a seismic station on such rocks ensures the background noise to be low. Two of the stations (namely KW04 and KW05) are located on a sedimentary layer; their background noise level is on average higher with respect to the other stations.
The PSD in Fig. 4, for low frequencies (less than $1 \mathrm{~Hz}$ ) span from -180 to $-130 \mathrm{~dB}$, close to the low noise Peterson's reference curve (Peterson, 1993). The worse performances belong to KW04 and KW05 reaching -130 and $-135 \mathrm{~dB}$ for low frequencies. High frequency peaks appear particularly at stations KW06 and KW03. These are located at ground floor levels of inhabited farms.

In the range of frequency needed for our analysis (0.5$4 \mathrm{~Hz}$ ), PSD values are close to the low noise level, and therefore we regard the station deployment as satisfying.

\section{Discussion}

The final geometry of the installed seismic network resulted from a good balance between site availability and ideal station location.

The seismic experiment started in June 2012 and finished in July 2014, in order to get full backazimuthal coverage of the teleseismic rays at each station, necessary to investigate 

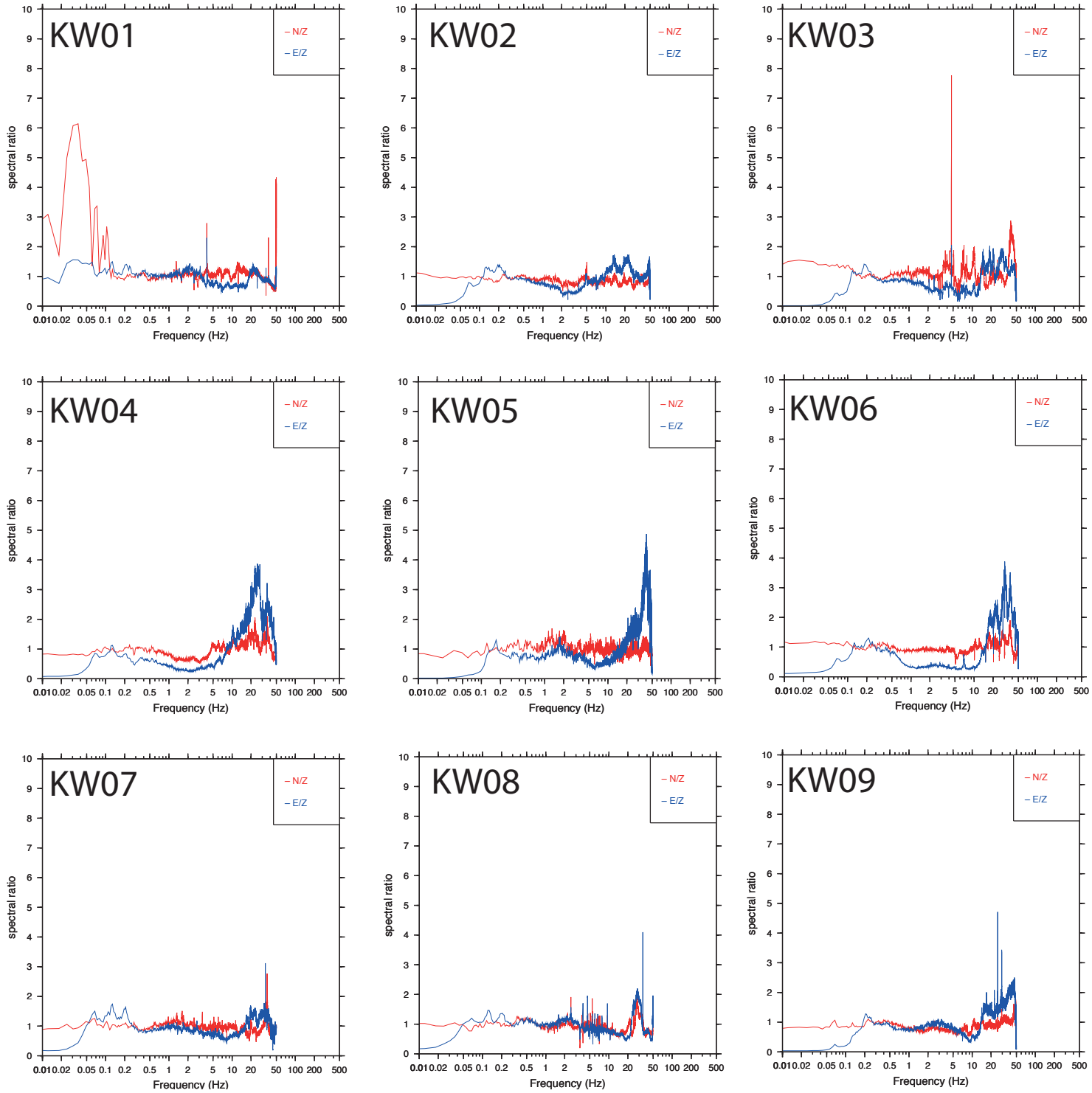

Figure 5. Spectral amplitude ratio of the two horizontal components ( $\boldsymbol{E}$ and $\boldsymbol{N})$ vs. the vertical component $(Z)$, modified after Nakamura (1989).

both the shallow and the deep crust, to unravel the seismic characteristics of the metamorphic Erbendorf body, and to explore the Saxoturingian-Moldanubian boundary zone.

\section{Network potential resolution}

In order to understand the potential resolution of the network with respect to the geometries of the structures below the surface, we show the hit surfaces of the teleseismic rays at 10 and $30 \mathrm{~km}$ depth, in Fig. 6a and b, respectively.

As deduced from Fig. 6a, 3 stations (KW01, KW06 and KW08) will sample the area above the Erbendorf body, entirely from the surface to its depth (at least $9 \mathrm{~km}$ ). Data recorded at these stations have the potential of revealing the anisotropy of the metamorphic body. The other stations sam- ple the surrounding area; teleseismic rays arriving at these stations are expected to sample the Erbendorf body at greater depth, if present.

The full ray coverage of the area at $30 \mathrm{~km}$ depth (Fig. 6b) will provide information on the buried boundary between the Saxoturingian and Moldanubian terrain, which nature, extent and location is still unclear, despite the intense seismic studies performed in the past in this area (Gebrande et al., 1991).

\section{Conclusions}

The passive seismic experiment at KTB started on June 2012 and finished in July 2014, during which a continuous seismic dataset at 9 sites has been acquired. Combining this dataset 

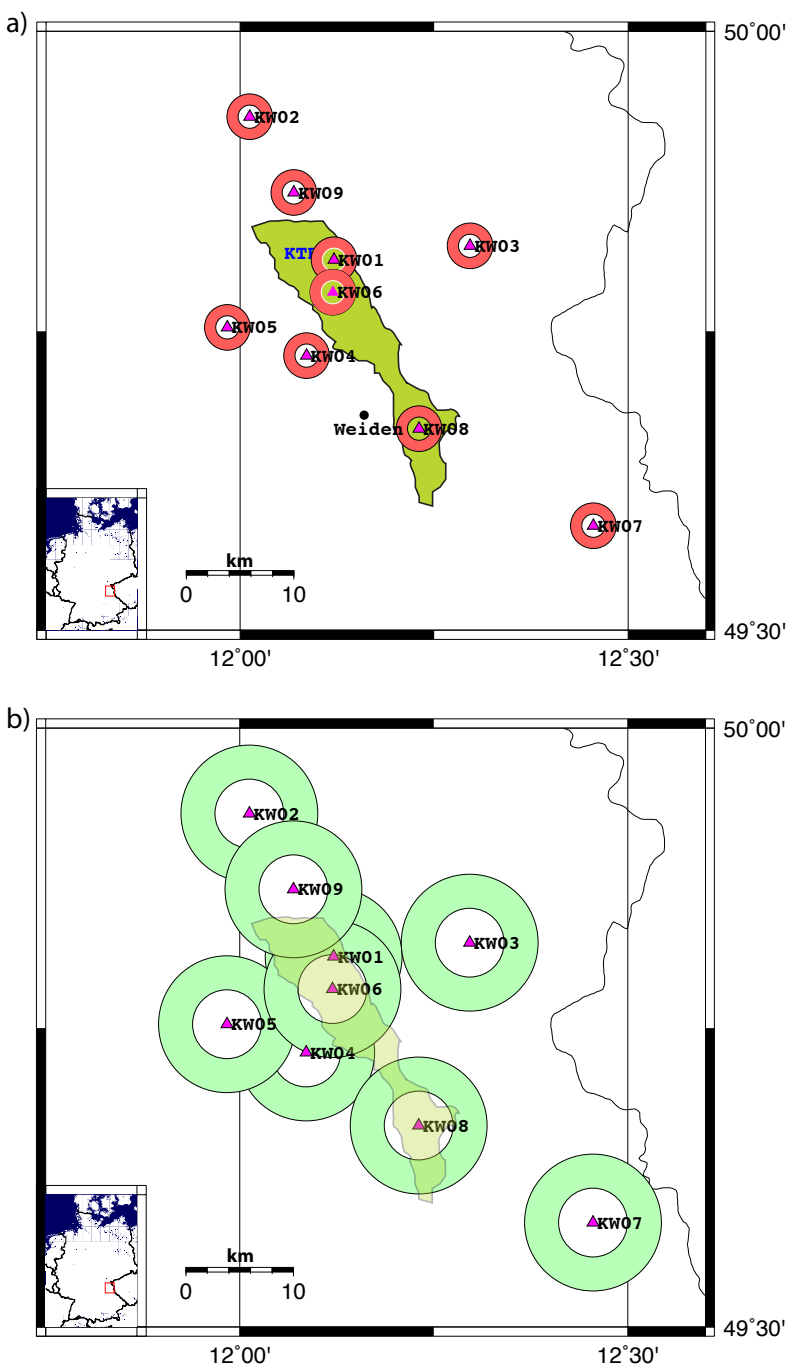

Figure 6. Map of the study area, with station location, the location of the metamorphic Erbendorf body at surface (green), and the areal coverage of teleseismic rays projected at surface for $10 \mathrm{~km}$ (a) and $30 \mathrm{~km}$ (b), considering epicentral distances of the incoming rays between 30 an 100 .

with the records at the two permanent stations (Bayern Network) in the area, and collecting data from past passive seismic experiments provided a large number of seismic records which rays sample the subsurface structures from all directions. The main goal is to determine the anisotropic characteristics of the Erbendorf body and to compare them with the direct information from rock samples extracted till $9 \mathrm{~km}$ depth, in order to understand which of the intrinsic characteristics of the rocks cause the anisotropy effect often observed in seismic records.

The receiver function data set is a useful tool to unravel the presence of discontinuities at depth, allowing us to explore the whole crust, with the aim of deciphering the nature and location of the hidden Saxothuringian-Moldanubian boundary in the crust. 


\section{Appendix A}

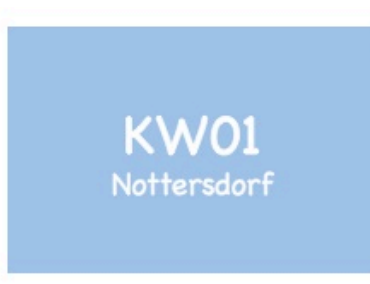

\begin{tabular}{r|l}
\hline INSTALLATION \\
IN & 09.07 .2012 \\
OUT & 14.07 .2014 \\
LAT & 49.8059 \\
LON & 12.1192
\end{tabular}

IMGW@KTB
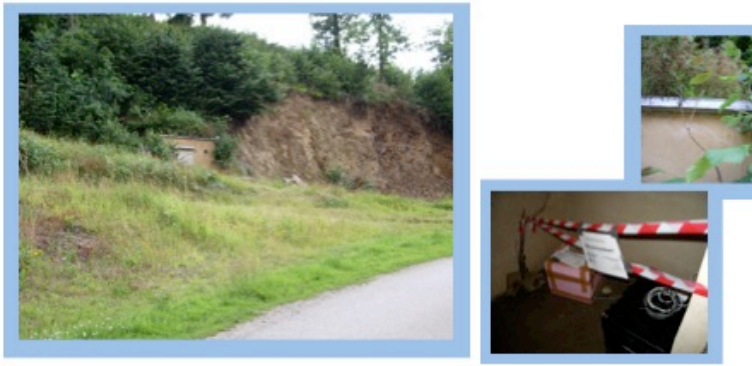

This station is located few hundreds meters from the KTB drilling site, in the seismic vault constructed in the '90s to monitor the seismic activity around the KTB site. Although recently used only as storage room, it was possible to exploit it again for our experiment. The site lies directly on the ZEV metamorfic body drilled till $9 \mathrm{~km}$ depth.

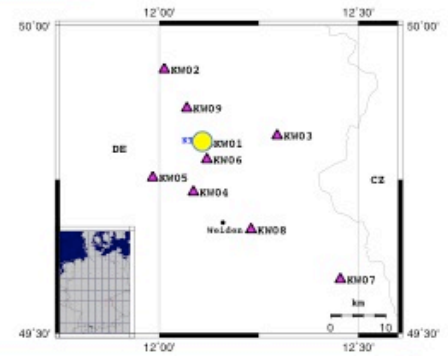

Figure A1. Station KW01 technical information.

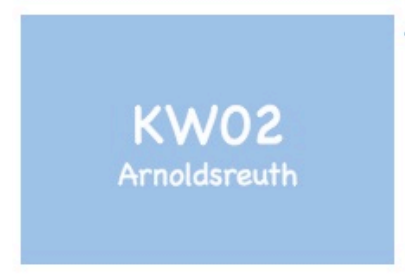

The station is located in the basement of a empty house. It is the northernmost site of the network.
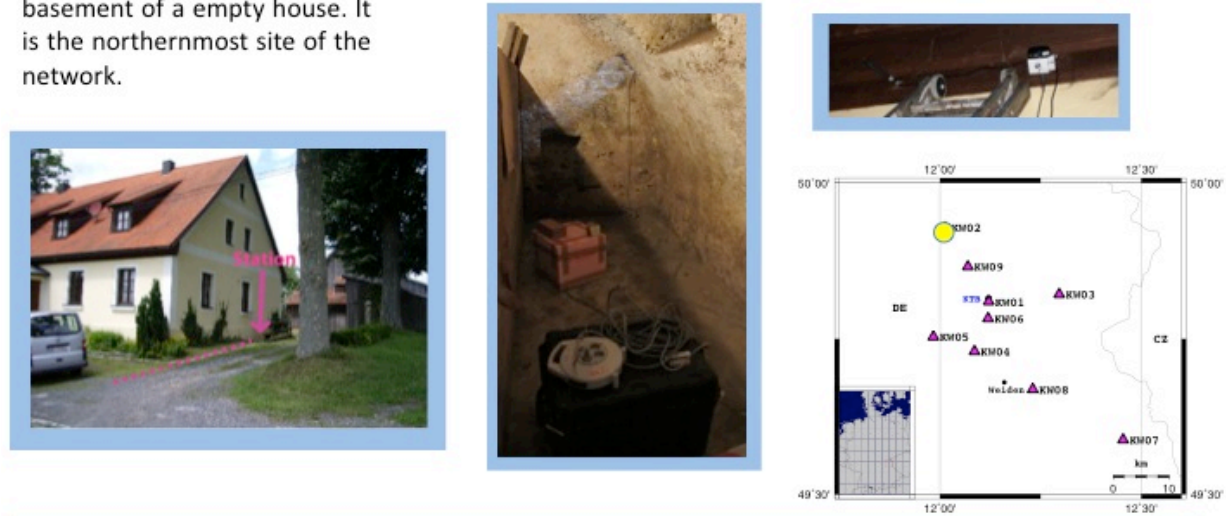

We thank the kindness and availability of the owners

Figure A2. Station KW02 technical information. 


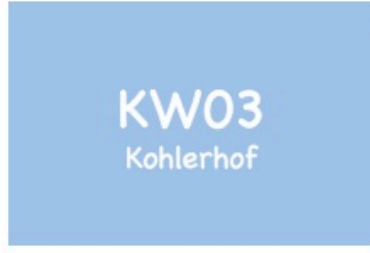

The station is located at the ground floor, in a storage room of a living house. This is the easternmost station of the network.

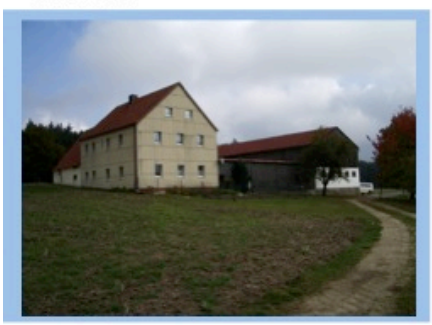

On 19.03.2013 seismic sensor and DAS were replaced

\begin{tabular}{r|lr|l}
\multicolumn{2}{c}{ IMGW@ KTB } \\
\hline INSTALLATION & \multicolumn{2}{c}{ EQUIPMENT } \\
IN & 10.07 .2012 & SENSOR & REF TEK BB 151-60 \\
OUT & 14.07 .2014 & RECORDER & REF TEK 130 \\
LAT & 49.8195 & GPS & REF TEK GARMIN \\
LON & 12.2913 & POWER & ELECTRICITY \\
& & BATTERY & 85Ah
\end{tabular}
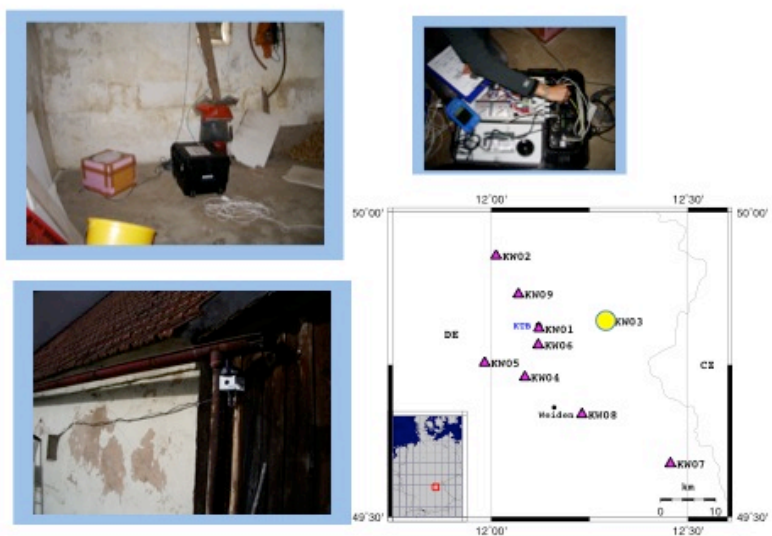

We thank the kindness and availability of the owner and his neighbors

Figure A3. Station KW03 technical information.

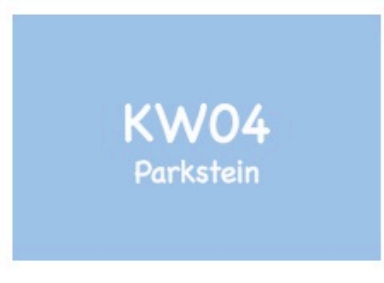

\begin{tabular}{r|lr|l} 
& & \multicolumn{1}{c}{ IMGW@ KTB } \\
\hline INSTALLATION & \multicolumn{2}{c}{ EQUIPMENT } \\
IN & 10.07 .2012 & SENSOR & REF TEK BB 151-60 \\
OUT & 15.07 .2014 & RECORDER & REF TEK 130 \\
LAT & 49.7246 & GPS & REF TEKGARMIN \\
LON & 12.0846 & POWER & ELECTRICITY \\
& & BATTERY & 85Ah
\end{tabular}

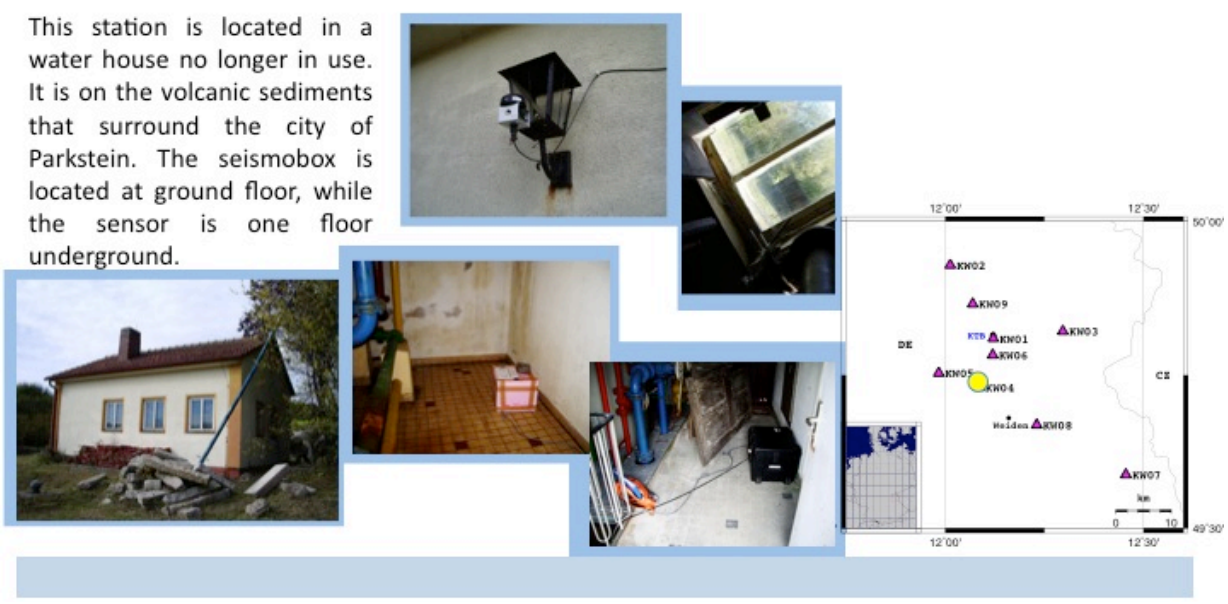

Figure A4. Station KW04 technical information. 

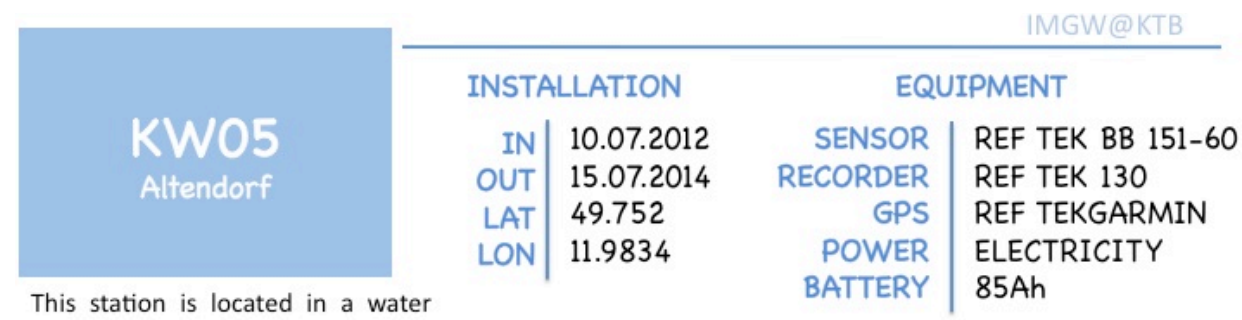

house no longer in use, in the woods few meters out of the small urban agglomerate of Altendorf. Sensor and seismobox are located inside the house, antennas are on the roof. Electricity comes from a neighboring holiday house.
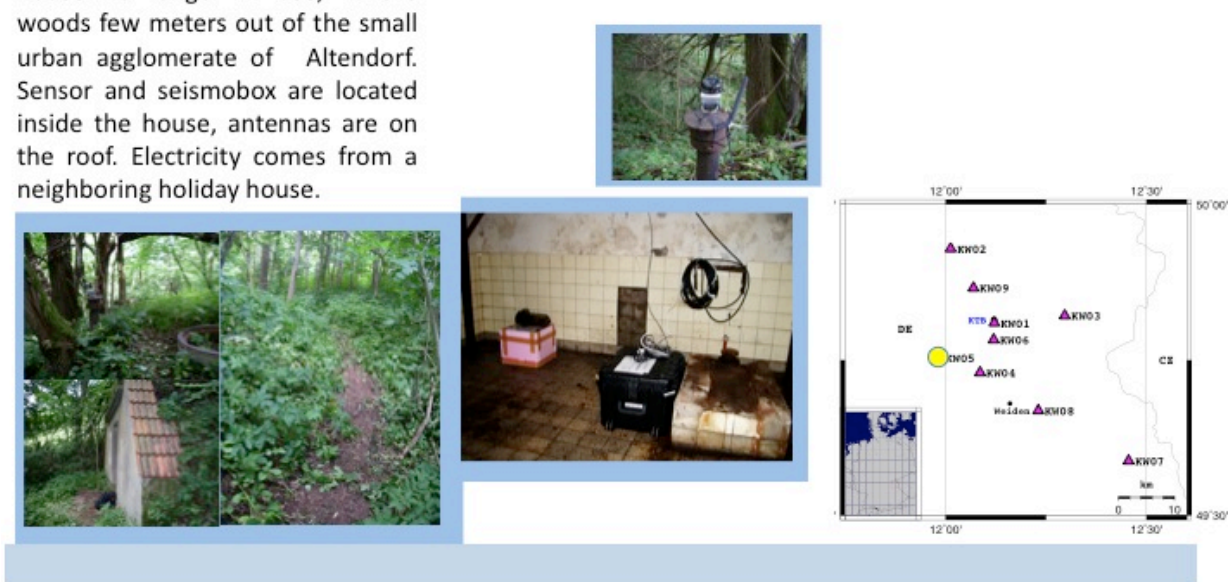

Figure A5. Station KW05 technical information.
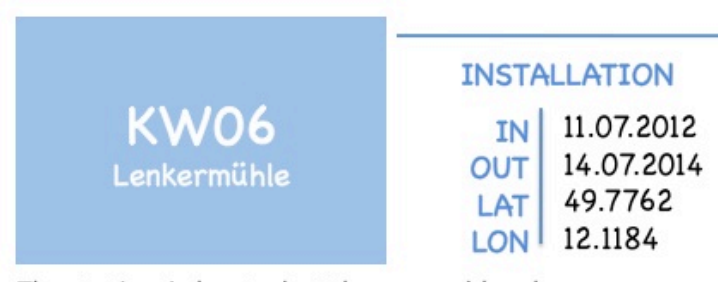

The station is located at the ground level in a ground floor empty room. This station has so far the worse GSM connection among all.
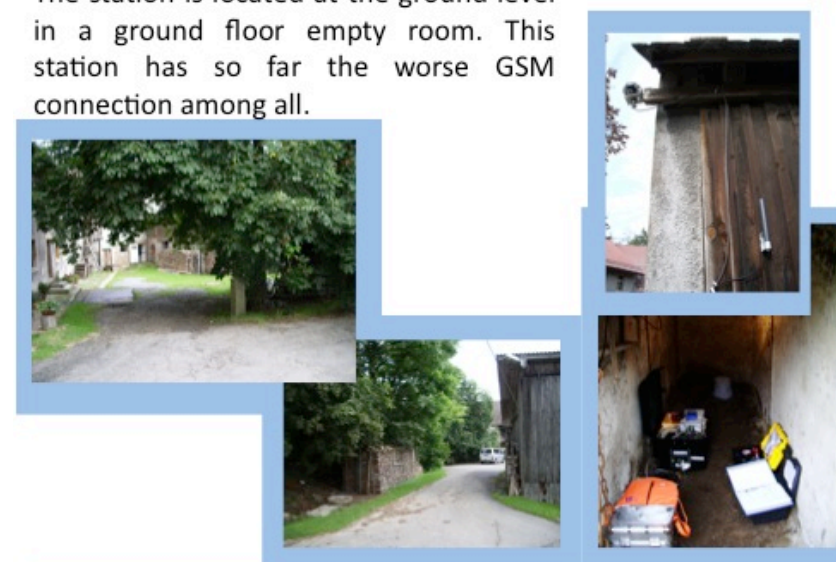

\section{EQUIPMENT}

IMGW@KTB

We thank the kindness and availability of the owners

Figure A6. Station KW06 technical information. 


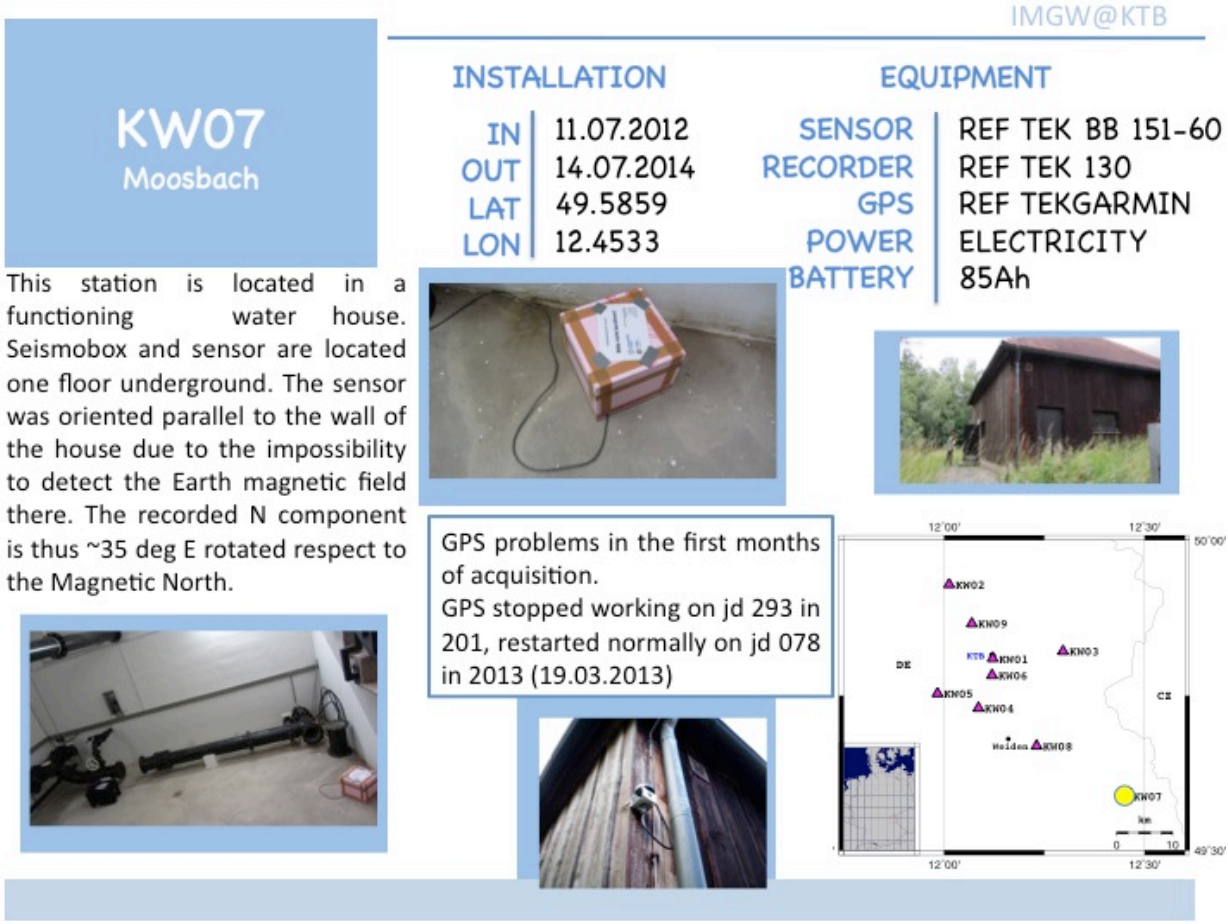

Figure A7. Station KW07 technical information.
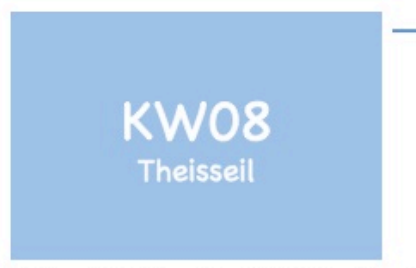

This station is locat

The seismobox is is one floor underground, while the sensor is two floors underground potentially making of this one of the best sites for recording. The water pumps are active every night for $40 \mathrm{~m}$ after midnight.

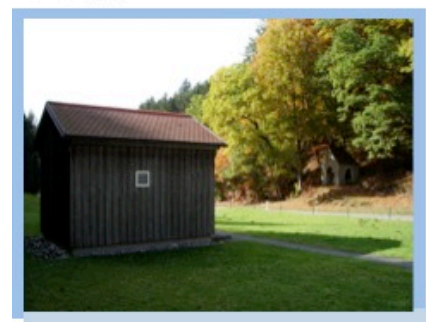

\begin{tabular}{r|lr|l}
\multicolumn{1}{c}{ INSTALLATION } & \multicolumn{2}{c}{ EQUIPMENT } \\
IN & 10.07 .2012 & SENSOR & REF TEK BB 151-60 \\
OUT & 03.07 .2013 & RECORDER & REF TEK 130 \\
LAT & 49.668 & GPS & REF TEK GARMIN \\
LON & 12.225 & POWER & ELECTRICITY \\
& & BATTERY & 85Ah
\end{tabular}

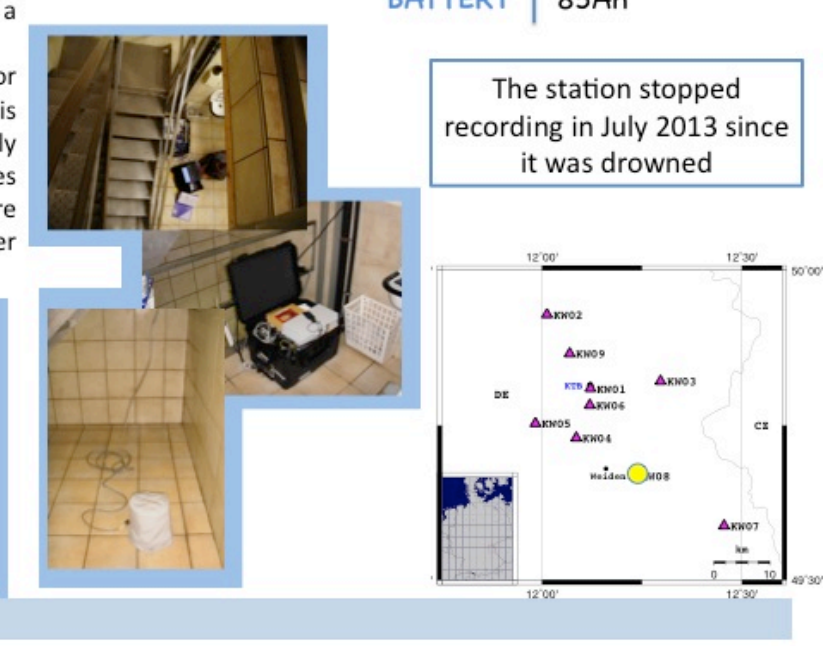

Figure A8. Station KW08 technical information. 


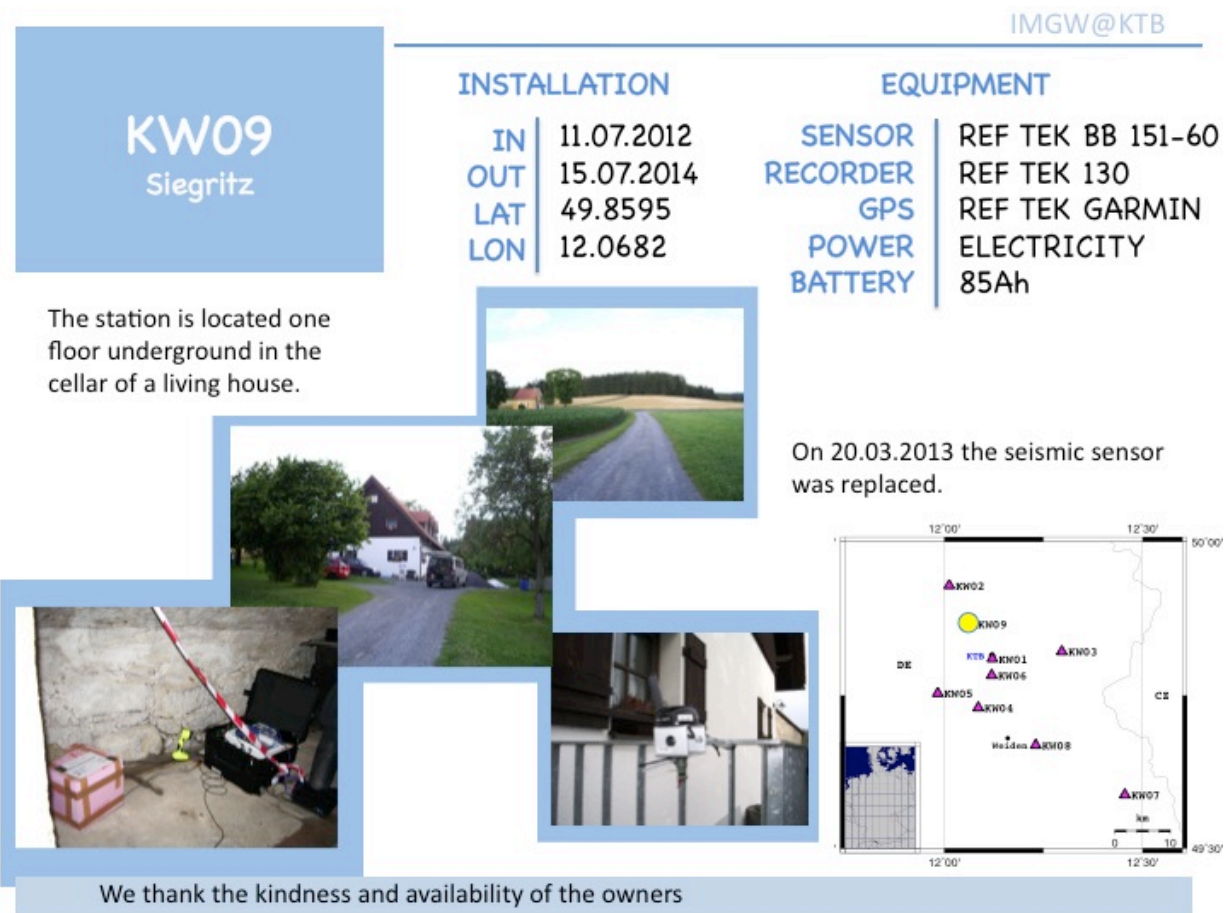

Figure A9. Station KW09 technical information. 
Acknowledgements. We thank Hans-Albert Dahlheim for his precious advice, and help during the field campaign. We are also grateful to Franz Holzförster, scientific director of the KTB Geozentrum, for giving us the opportunity to use the spaces of the geo-center. We thank P. Jordakiev, P. Arneitz and A. Gerner for their help during the installation campaign. We acknowledge funding by the Austrian Science Fund (FWF): 24218. Our acknowledgements go to J. Plomerova and T. Plenefisch for their comments that contribute improving our manuscript.

Edited by: D. Pesaresi

Reviewed by: T. Plenefisch and J. Plomerova

\section{References}

Babuska V. and Plomerova J.: Boundaries of mantle-lithosphere domains in the Bohemian Massif as extinct exhumation channels for high-pressure rocks, Gondwana Res., 23, 973-987, doi:10.1016/j.gr.2012.07.005, 2013.

Dahlheim, H. A., Gebrande, H., Schmedes, E., and Soffel H.: Seismicity and stress field in the vicinity of the KTB location, J. Geophys. Res., 102, 493-506, 1997.

DEKORP Research Group: Near-vertical and wide-angle seismic surveys in the Black Forest, SW Germany, J. Geophys., 62, 130, 1987.

DEKORP Research Group: Results of the DEKORP 4/KTB Oberpfalz deep seismic reflection investigations, J. Geophys., 62, 69$101,1988$.

DEKORP and Orogenic processes Working Groups: Exhumation of subducted crust - the Saxonian granulites from reflection seismic experiment GRANU' 95. Tectonics, 18, 756-773, 1999.

Eisbacher, G.-H., Lüschen, E., and Wickert, F.: Crustal-scale thrusting and extension in the Hercynian Schwarzwald and Vosges, Central Europe, Tectonics, 8, 1-21, 1989.

Emmermann, R. and Lauterjung, J.: The German Continental Deep Drilling Program KTB: Overview and major results, J. Geophys. Res., 102, 179-201, 1997.

Emmermann, R. and Wohlenberg, J.: The German continental deep drilling program (KTB): Site-selection studies in the Oberpfalz and Schwarzwald, Springer, Berlin-Heidelberg, 553 pp., 1989.

Gebrande, H., Bopp, M., MeichelböCk, M., and Neurieder, P.: 3D Wide-Angle Investigations in the Ktb Surroundings as Part of The "Integrated Seismics Oberpfalz 1989 (Iso89)", First Results, in: Continental Lithosphere: Deep Seismic Reflections, edited by: Meissner, R., Brown, L., Dürbaum, H.-J., Franke, W., Fuchs, K., and Seifert, F., American Geophysical Union, Washington, DC, doi:10.1029/GD022p0147, 1991.
Haak, V. and Jones, A. G.: Introduction to special section: the KTB deep drill hole, J. Geophys. Res., 102, 175-177, 1997.

Harjes, H. P., Bram, K., Dürbaum, H.-J., Gebrande, H., Hirschmann, G., Janik, M., Klöckner, M., Lüschen, E., Rabbel, W., Simon, M., Thomas, R., Tormann, J., and Wenzel, F.: Origin and nature of crustal reflections: Results from integrated seismic measurements at the KTB superdeep drilling site, J. Geophys. Res.-Sol. Ea., 102, 18267-18288, 1997.

Lüschen, E., Bram, K., Söllner, W., and Sobolev, S.: Nature of seismic reflections and velocities from VSP-experiments and borehole measurements at the KTB deep drilling site in southeast Germany, Tectonophysics, 264, 309-326, 1996.

Marzorati, S. and Bindi, D.: Ambient noise levels in north central Italy. Geochem. Geophys. Geosyst., 7, Q09010, doi:10.1029/2006GC001256, 2006.

Muller, J., Janik, M., and Harjes, H.-P.: The use of wave-field directivity for velocity estimation: Moving source profiling (MSP) experiments at KTB, Pure Appl. Geophys., 156, 303-318, 1999.

Nakamura, Y.: A method for dynamic characteristics estimation of subsurface using microtremor on the ground surface, QR Railway Tech. Res. Inst., 30, 1, 1989.

O’Brien, P. J., Duyster J., Grauert B., Schreyer W., Stoeckhert W., and Weber, K.: Crustal evolution of the KTB drill site: From oldest relics to the late Hercynian granites, J. Geophys. Res.-Sol. Ea., 102, 18203-18220, 1997.

Okaya, D., Rabbel W., Beilecke T., and Hasenclever, J.: P wave material anisotropy of a tectono-metamorphic terrane: An active source seismic experiment at the KTB super-deep drill hole, southeast Germany, Geophys. Res. Lett., 31, L24620, doi:10.1029/2004GL020855, 2004.

Peterson, J.: Observation and modeling of seismic background noise, U.S. Geol. Surv. Tech. Rept., 93-322, 1-95, 1993.

Plenefisch, T., Klinge, K., and Kind, R.: Upper mantle anisotropy at the transition zone of the Saxothuringicum and Moldanubicum in southeast Germany revealed by shear wave splitting. Geophys. J. Int., 144 309-319, 2001.

Plomerová, J., Achauer, U., Babuška, V., Vecsey, L., and BOHEMA working group: Upper mantle beneath the Eger Rift (Central Europe): Plume or asthenosphere upwelling?, Geophys. J. Int., 169, 675-682 doi:10.1111/j.1365-246X.2007.03361.x, 2007. 